\title{
Feeding habits of fish from a stream in the savanna of Central Brazil, Araguaia Basin
}

\author{
Cesar Enrique de Melo*, Francisco de Arruda Machado** and Vangil Pinto-Silva**
}

The objective of the present study was to determine the composition of the diet of fish and its relation to the condition of canopy along a stream in the savanna of Central Brazil. Fish were collected monthly from April 1994 to March 1995. A total of 3872 individuals belonging to 82 species were captured and 1606 of them had their stomach content analysed. Allochthonous resources were widely used by fish. Although some fish groups do present generalist habits, most of the species can be included in well-defined trophic groups. Piscivores were abundant only during the flooding season when they occupied the stream looking for food and reproduction sites. Deforestation of the riparian forest has negative effects on the fish populations that depend on allochthonous resources. Lack of vegetation near the mouth of the river allows sand accumulation on the bottom of the stream and destruction of important microhabitats used as feeding and shelter, a fact that excluded some species from this site.

Este trabalho teve como objetivo determinar a composição da dieta dos peixes e sua relação com a vegetação marginal em um córrego de cerrado no Brasil Central. Os peixes foram coletados mensalmente de abril de 1994 a março de 1995. No total, foram capturados 3872 indivíduos, distribuídos em 82 espécies, destes, 1606 foram submetidos à análise de conteúdo estomacal. Recursos alóctones foram amplamente utilizados pelos peixes. Embora existam grupos com hábitos alimentares generalistas, a maioria das espécies pôde ser incluída em grupos tróficos bem definidos. Piscívoros foram abundantes apenas no período de cheia, quando entram no córrego à procura de alimento e locais de reprodução. O desmatamento da vegetação marginal apresentou efeito negativo sobre a população de peixes que depende de recursos alóctones. A falta de vegetação, próximo à foz do córrego, facilitou assoreamento e destruição de importantes microhabitats usados para alimentação e esconderijo, fato que impediu a permanência de algumas espécies no local.

Key words: Neotropical fishes, fish ecology, trophic interactions, riparian forest, cerrado.

\section{Introduction}

In the Amazon region, clear water rivers usually are extremely poor in nutrients but can support a very rich fish fauna (Fittkau, 1967; Lowe-McConnell, 1987). This apparently paradoxical situation was clarified by studying feeding habit of fish living in that region (Gottsberger, 1978). In Amazonian streams, riparian forest blocks part of sunlight and prevents high primary production and in these locations, most fish species use food items of allochthonous origin which can maintain complex food webs (Lowe-McConnell, 1987). Generalistic species are predominant among fishes and there is a strong tendency towards omnivory (Lowe-McConnell, 1987).
This feeding strategy may also be present in savanna streams since the environment is poor in nutrients and, therefore, food resources for fish are mainly supplied by the forest canopy (Mason \& MacDonald, 1982; Henry et al.,1994; Esteves \& Lobón-Cerviá, 2001). Degradation of the Brazilian savanna over the last decades for implantation of exotic cultures promptly affected rivers of the region (Novaes-Pinto, 1993). Thus, ecological studies of the aquatic fauna are urgently needed, since large part of it is still unknown (Vari \& Malabarba, 1998). These studies are imperative for future projects of conservation of fish fauna in the Brazilian savanna. The present study describes the diet of fish along a stream in the savanna of Central Brazil and discusses the effect of stream banks deforestation on the maintenance of several trophic categories.

\footnotetext{
*Laboratório de Ictiologia e Limnologia, Depto. de Ciências Biológicas, Universidade do Estado de Mato Grosso, BR 158, km 148, 78690-000 Nova Xavantina, MT, Brazil. e-mail: meloce@yahoo.com

**Instituto de Biociências, Universidade Federal de Mato Grosso, Av. Fernando Correa s/n, 78060-900 Cuiabá, MT, Brazil.
} 


\section{Material and methods}

This study was conducted in the Córrego Fundo stream, a third order stream according to the Horton classification, with an extension of approximately $22 \mathrm{~km}$, located in the municipality of Barra do Garças, State of Mato Grosso, Brazil (1552'12'S, 52¹8'24”W). The source of the Córrego Fundo stream is located in the Taquaral mountain range and its mouth in the rio das Garças, in the basin of the rio Araguaia. Córrego Fundo stream drains a savanna region with sandy soils poor in nutrients.

Five sampling stations were selected, each with an extension of about $300 \mathrm{~m}$ (Fig. 1): station A, located in the first portion of the upper course, where water presents a minimum flow during the dry period and substrate is rocky; this area is fully covered with canopy forest. Station B is located $7 \mathrm{~km}$ downstream from station $\mathrm{A}$, it is meandering and is inserted in an area of intense ranching; marginal vegetation consists only of introduced pasture. Station C, $8 \mathrm{~km}$ downstream from station B, presents several stretches with a depth of $1 \mathrm{~m}$ or more and well-preserved marginal vegetation; sandy soil predominates, with fine pebbles at some points. In station $\mathrm{D}$, approximately $1 \mathrm{~km}$ downstream from station $\mathrm{C}$, marginal vegetation is quite altered, with few points of native vegetation. At this site water is rapid and rocky bottom prevails. Station E is close to the confluence with rio das Garças; in this area, grass and herbaceous plants represent the largest portion of the marginal vegetation, with presence of few trees. At several points margins are deforested and the bed of the stream is shoaled. During the rainy season, water level in this station rises and margins are flooded due to the increase in water volume in the rio das Garças, which invades the Córrego Fundo stream.

Fish were collected monthly from April 1994 to March 1995. During each month all five stations were sampled on the same day. Sampling times at the stations were changed from one month to the other in order to collect at various times of day at each station.

Equipments used for sampling were: seining net (3 $\mathrm{m} \times 1$ $\mathrm{m}, 5 \mathrm{~mm}$, mesh); gill nets ( $10 \mathrm{~m} \times 1.5 \mathrm{~m}, 3,6$ and $12 \mathrm{~mm}$, mesh) (Oyakawa \& Esteves, 2004); cast net (mesh $25 \mathrm{~mm}$ and $2.5 \mathrm{~m}$ height); dip net (600 $\mathrm{mm}$ in diameter, mesh $2 \mathrm{~mm}$ ) and hooks on lines, which were set up in the margins and in the middle of the stream. Cast and seining nets were used during 30 minutes of sampling in each station. Hooks and gill nets were used for two hours of sampling at each station, from 6:00 am to 7:00 pm, with a total of 24-hour-effort for each station and equipment.

Fishes were fixed in the field in $10 \%$ formalin and transferred to $70 \%$ ethanol. Voucher specimens were deposited in the Ichthyological Collection of the Laboratório de Ictiologia e Limnologia of the Universidade do Estado de Mato Grosso, Nova Xavantina, Mato Grosso.

Food items were determined by analysis of the stomach contents carried out on 1606 specimens, corresponding to $41.47 \%$ of the total collected. At least $28 \%$ of the individuals

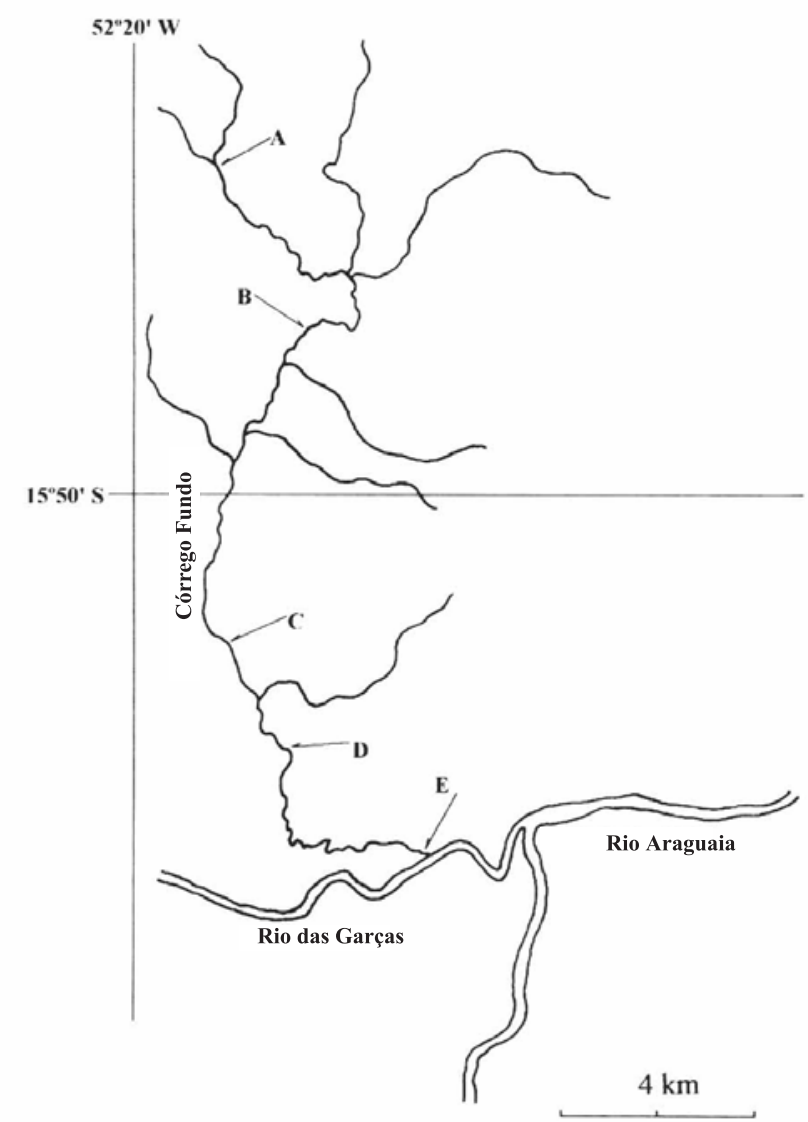

Fig. 1. Location of the Córrego Fundo stream and the five sampling stations, identified by arrows.

of each species were analyzed. For species with five or fewer individuals all stomachs were analyzed. Food items were deposited on a Petri dish over graph paper for determination of the area and volume occupied by each item. Height of the material was standardized at $1 \mathrm{~mm}$ and, the proportional volume ingested was determined based on the area occupied (Esteves \& Lobón-Cerviá, 2001). Analyses were performed with a stereomicroscope. Small-sized items such as detritus were analyzed under a common light microscope. Trophic groups were determined by cluster analysis using the UPGMA method with euclidean distances (Krebs, 1989).

Food resources were identified and divided into 10 broad categories: 1) aquatic insects - consisting of larvae, nymph and adult insects; 2) terrestrial insects; 3) arthropod remains - remains not identified; 4) fish - flesh remains or whole individuals; 5) scales - fish scales; 6) leaves and flowers; 7) fruits and seeds - complete structures or parts of them; 8) filamentous algae; 9) detritus - finely triturated material, generally containing grains of sand; 10) other - rare items and unidentified material. 


\section{Results}

A total of 3872 fish distributed into 82 species were collected. Among them 1606 individuals belonging to 71 species were analyzed (Table 1). Twenty specimens belonging to 11 species which presented empty stomachs were excluded from the study (Argonectes scapularis, Astyanax sp. 6, Crenicichla sp. 3, Raphiodon vulpinus, Retroculus sp., Trichomycterus sp. 1, Pimelodus ornatus, Hemisorubim platyrhynchos, Trichomycterus sp. 2, Hoplias malabaricus, and Corydoras sp.). In about $45 \%$ of the species (Table 1), food of allochthonous origin represented at least $20 \%$ of the volume ingested. Among these species there are some numerically most representative in the system such as Hemigrammus sp. and Rivulus zigonectes. For Hemigrammus sp., although arthropod remains predominated in the diet $(65 \%)$, other items of allochthonous origin were also abundant, such as leaves and flowers, fruits and seeds, and terrestrial insects.

Fruits and seeds were more important in the diet of eight species, specially for the four species of the genus Astyanax whose diets contained $45.3 \%$ to $73.7 \%$ of this item. Fruits and seeds were not ingested by any abundant species at Station $\mathrm{D}$, where water is fast.

Although autochthonous material was relatively less important, it represented more than $20 \%$ of the volume ingested by approximately $38 \%$ of the species analyzed. Among these species are Pseudoloricaria sp., the only that mainly fed on filamentous algae which composed about $75 \%$ of its diet, and Eigenmannia trilineata that mainly ate aquatic insects, which represented $81.7 \%$ of its diet.

Detritus occurred in about $23 \%$ of the species studied, whose stomach contents consisted of at least $20 \%$ of this item. It represented $83 \%$ of the diet of Parotocinclus britskii and $43.8 \%$ of the diet of Odontostilbe sp.

Main food resources taken by fish in the Córrego Fundo stream are showed in Fig. 2. The proportion of fish consuming aquatic insects (Fig. 2a) increased from the source to station $\mathrm{D}$ and decreased at station E. Fish consuming fruits and seeds (Fig. 2b) were present in low proportions at station B, but they were important at the others. Detritivores (Fig. 2c) occurred in similar proportions at stations B, C and D and were absent at station A. Feeding on terrestrial insects (Fig. 2d) were predominant at station A, absent at station D and rare at station $\mathrm{B}$.

The dendrogram based on food items ingested by fish (Fig. 3) demonstrates the occurrence of nine trophic groups consisting of at least three species. Group I consists of three species that ingest algae. Group II, represented by detritivores, comprises 14 species. Group III consists of four species that mainly feed on leaves and flowers. Group IV includes 11 fish species that eat aquatic insects. Group V consists of four species whose stomachs contained large amounts of arthropod remains. Group VI consists of six species preferentially feeding on fruits and seeds. Group VII, with

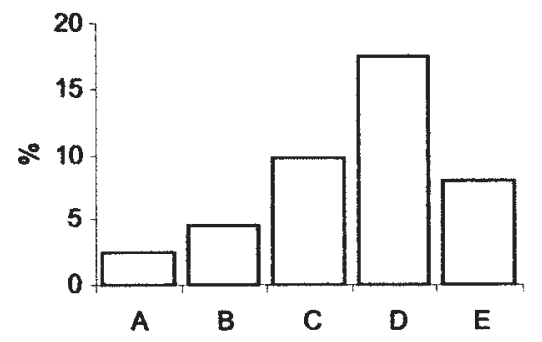

a

Sampling stations

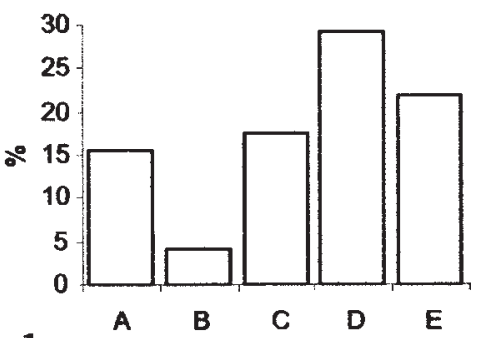

b Sampling stations

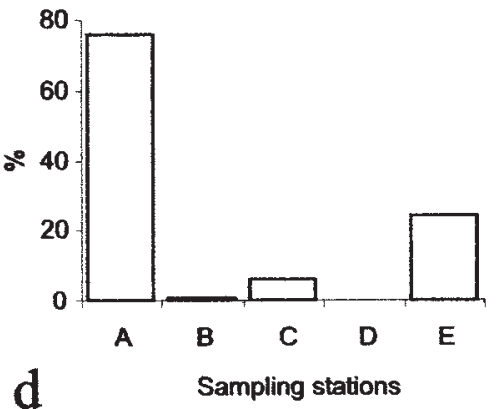

Fig. 2. Relative frequency of individuals that feed on aquatic insects (a), fruits and seeds (b), detritus (c) terrestrial insects (d), at the sampling stations A, B, C, D, and E. 


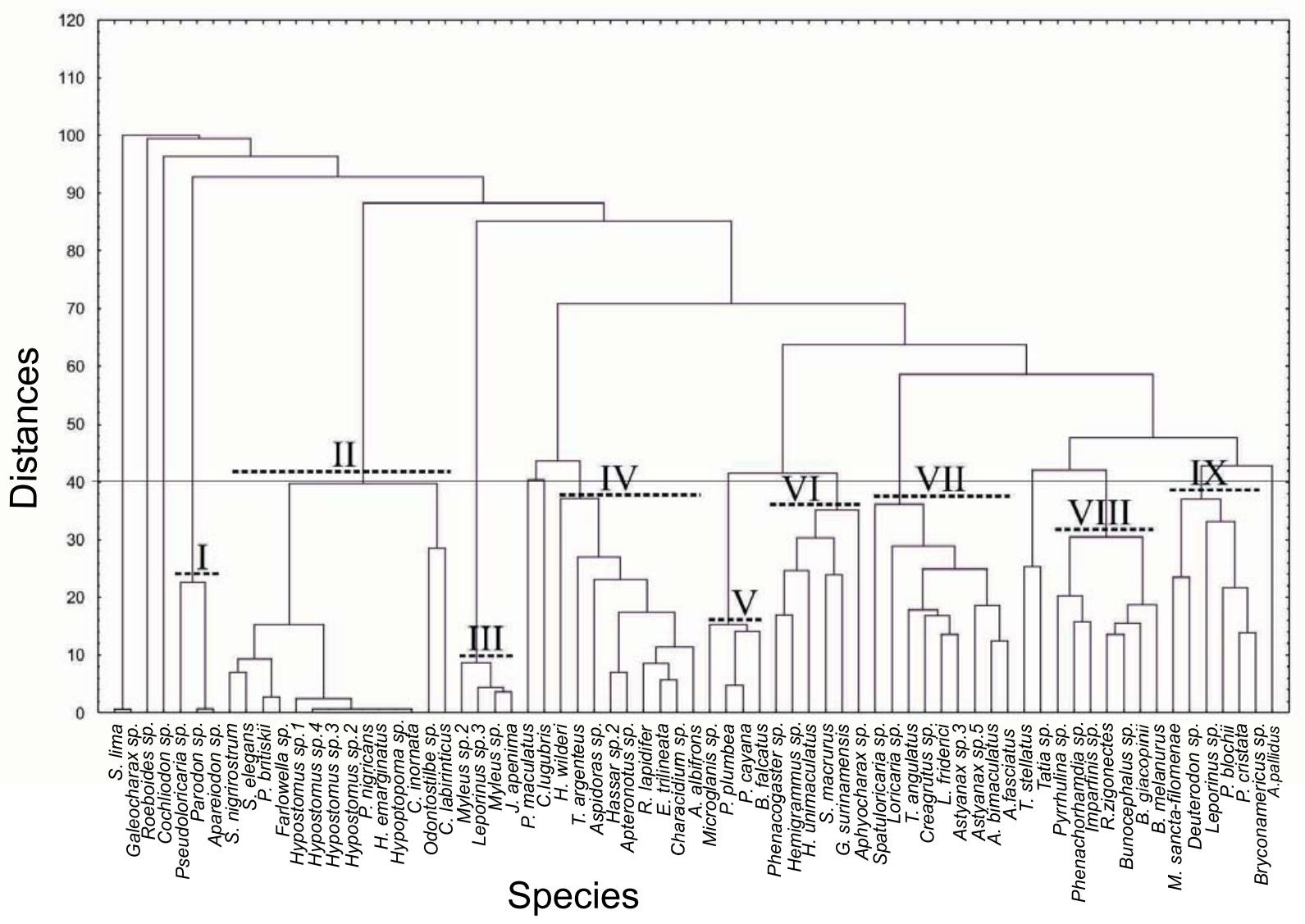

Fig. 3. Tree diagram of the main trophic groups of fish from Córrego Fundo stream, based on stomach content analysis. Dashed lines indicate the trophic groups.

nine species, includes terrestrial insect eaters. This group includes three species whose diet presents a large proportion of arthropod and aquatic insect remains. Group VIII comprises seven insectivores species which predominantly feed on terrestrial insects. Group IX comprises six species with more generalist habits, whose diet includes considerable amounts of leaves and flowers, fruits and seeds, in addition to smaller amounts of insects.

\section{Discussion}

The increase in the proportion of fish that consume aquatic insects from the source to station $\mathrm{D}$ agrees with the prediction of the River Continuum Concept proposed by Vannote et al. (1980), since greater deposition of organic matter occurs in the lower regions of the stream, facilitating the establishment of insects in the substrate. At Station E this proportion fall due to the siltation caused by bank destruction, preventing the establishment of a more numerous aquatic insect fauna due to the absence of adequate substrates (Allan, 1995).

A food item widely used by fish is arthropod remains which may represent an important part of diet. However, this type of food has not been considered in depth in previous studies, possibly because these are considered to be remains of semidigested organisms that were captured whole. Although this may be partly true, some fish species are adapted to capture this type of food. This may be advantageous since these remains maintain the nutritional characteristics of whole arthropods, as high protein content. Besides, they can be easily collected when they drift, and also, they present no defense. In addition, they do not depend on the local condition of the riparian forest because they may be provided by forest located upstream. Hemigrammus sp. and Pyrrhulina sp. capture these items selectively in small marginal pools, while Bryconamericus sp. select them in running water sites, where the items are carried into its direction. The use of this strategy explains the high frequency of these species even at sites where the riparian forest has already been destroyed.

Fruits and seeds are much abundant and extensively used by fish in South America, with no ecological equivalents in any other place in the world (Goulding, 1980). This feeding strategy allows saving energy in the search for higher quality foods (Prejs \& Prejs, 1987).

In station A, fish feeding is related to the canopy forest. All species of this station ingest relatively large amounts of terrestrial insects, fruits, seeds, leaves, and flowers, demonstrating a strong influence of the vegetation on the 
Table 1. Relative volume (\%) of the food items in the diet of fishes collected in the Córrego Fundo stream, between April 1994 and March 1995. (AI) Aquatic insects; (TI) terrestrial insects; (LF) leaves and flowers; (DT) detritus; (FS) fruits and seeds; (AR) arthropod remains; (SC) scales; (FA) filamentous algae; (FH) fish; (OT) others; $\mathrm{N}$ = number of individuals analyzed. Species with empty stomachs were not included in this table. The taxonomical order is adapted from Britski et al. (1999).

\begin{tabular}{|c|c|c|c|c|c|c|c|c|c|c|c|c|c|c|c|c|c|}
\hline \multirow[b]{2}{*}{$\begin{array}{c}\text { Families/species } \\
\end{array}$} & \multirow[b]{2}{*}{$\mathrm{AI}$} & \multicolumn{8}{|c|}{ Types of food (\%) } & \multirow{2}{*}{\multicolumn{2}{|c|}{ OT }} & \multicolumn{4}{|c|}{ Abundance } & \multirow[b]{2}{*}{$E$} & \multirow[b]{2}{*}{ Total } \\
\hline & & TI & LF & DT & FS & $\mathrm{AR}$ & $\mathrm{SC}$ & FA & FH & & & $\mathrm{A}$ & $\mathrm{B}$ & $\mathrm{C}$ & $\mathrm{D}$ & & \\
\hline \multicolumn{18}{|l|}{ Pristigasteridae } \\
\hline Pristigaster cayana & & & & & & 100.0 & & & & & 1 & & & & & 1 & 1 \\
\hline \multicolumn{18}{|l|}{ Characidae } \\
\hline Aphyocharax sp. & 48.2 & & 6.5 & & 3.3 & 35.9 & & 3.3 & & 2.8 & 5 & & & 1 & & 5 & 6 \\
\hline Astyanax fasciatus & 8.7 & 10.7 & 26.7 & 2.7 & 45.3 & 2.3 & 0.2 & 0.3 & & 3.1 & 48 & & 10 & 38 & 24 & & 72 \\
\hline Astyanax bimaculatus & 4.3 & 9.8 & 19.6 & & 57.7 & 1.1 & 0.1 & 2.0 & & 5.4 & 31 & 2 & 32 & 22 & 24 & 1 & 81 \\
\hline Astyanax sp. 3 & & 6.3 & 16.5 & & 73.7 & 0.7 & & & & 2.7 & 14 & 13 & 7 & 4 & 6 & & 33 \\
\hline Astyanax sp. 5 & 0.4 & 23.9 & 8 & & 51.7 & 4.9 & & 6.4 & & 4.6 & 31 & 52 & 10 & & 3 & & 65 \\
\hline Brycon falcatus & & & & & 13.3 & 86.7 & & & & & 2 & & & & & 2 & 2 \\
\hline Bryconamericus sp. & 11.5 & 9 & 16 & 5.9 & 23.7 & 23.8 & 2.2 & 2.4 & & 5.4 & 71 & 3 & 58 & 106 & 27 & 1 & 195 \\
\hline Bryconops melanurus & 3.2 & 62.4 & & & & 33.7 & & & & 0.7 & 13 & & 2 & 19 & 1 & & 22 \\
\hline Bryconops giacopinii & 22.1 & 47.6 & 2.2 & & 0.2 & 19.6 & & 0.3 & 5.3 & 2.7 & 23 & & 12 & 20 & 2 & & 34 \\
\hline Creagrutus sp. & 12.9 & 6 & 4.9 & & 61.1 & 11.0 & 0.3 & 2.5 & & 1.3 & 53 & & 37 & 32 & 75 & 29 & 173 \\
\hline Galeocharax sp. & & & & & & & & & 100.0 & & 3 & & & & 1 & 2 & 3 \\
\hline Jupiaba apenima & 2.4 & 0.4 & 89.3 & & & & & 7.9 & & & 5 & & 6 & & 1 & & 7 \\
\hline Deuterodon sp. & 4.1 & 45.2 & 45.2 & & & & & 5.4 & & & 5 & & 3 & 1 & 2 & 1 & 7 \\
\hline Hemigrammus sp. & 6.2 & 4.2 & 14.1 & 0.4 & 4.9 & 65.1 & 0.1 & 1.8 & & 3.2 & 287 & & 962 & 30 & 7 & & 999 \\
\hline $\begin{array}{l}\text { Moenkhausia } \\
\text { sanctaefilomenae }\end{array}$ & 4.9 & 23.4 & 42.8 & & 8.3 & 17.0 & 3.0 & 0.6 & & & 47 & 12 & 45 & 25 & 2 & 4 & 88 \\
\hline Odontostilbe sp. & 6.9 & 2.3 & 9.4 & 43.8 & 0.1 & 5.8 & 0.1 & 21.5 & & 10.1 & 63 & & 89 & 67 & 32 & 8 & 196 \\
\hline Phenacogaster sp. & 17.4 & & 24.9 & & & 52.2 & & & & 5.5 & 11 & & 2 & 14 & & 11 & 27 \\
\hline Roeboides sp. & & & & & & & 100.0 & & & & 2 & & & & & 2 & 2 \\
\hline Tetragonopterus argenteus & 63.5 & 4.8 & & & 20.4 & & 11.3 & & & & 4 & & & & & 4 & 4 \\
\hline Triportheus angulatus & 11 & 1.3 & & & 83.3 & 4.4 & & & & & 4 & & & & 3 & 1 & 4 \\
\hline \multicolumn{18}{|l|}{ Serrasalmidae } \\
\hline Myleus sp. & 1.9 & & 90.1 & & 1.4 & 1.5 & 0.9 & 4.1 & & & 14 & & 15 & 1 & 1 & & 17 \\
\hline Myleus sp. 2 & & & 100 & & & & & & & & 1 & & 1 & & & & 1 \\
\hline \multicolumn{18}{|l|}{ Gasteropelecidae } \\
\hline Thoracocharax stellatus & & 71.3 & & & & 6.0 & & & & 22.7 & 7 & & & & & 10 & 10 \\
\hline Crenuchidae & & & & & & & & & & & & & & & & & \\
\hline Characidium sp. & 76.7 & 1.3 & 1.3 & 5.7 & & 8.8 & 0.6 & & & 5.6 & 36 & & 19 & 11 & 14 & 18 & 62 \\
\hline Parodontidae & & & & & & & & & & & & & & & & & \\
\hline Apareiodon sp. & & & & & & & & 100.0 & & & 5 & & & & 4 & 1 & 5 \\
\hline Parodon sp. & & & & & & & & 100.0 & & & 4 & & 1 & & 3 & & 4 \\
\hline Hemiodontidae & & & & & & & & & & & & & & & & & \\
\hline Hemiodus unimaculatus & 29.2 & & 0.1 & 0.1 & & 70.6 & & & & & 1 & & & & 1 & & 1 \\
\hline Prochilodontidae & & & & & & & & & & & & & & & & & \\
\hline Prochilodus nigricans & & & & 100 & & & & & & & 2 & & 1 & & 1 & & 2 \\
\hline Curimatidae & & & & & & & & & & & & & & & & & \\
\hline Curimata inornata & & & & 100 & & & & & & & 2 & & & & & 2 & 2 \\
\hline Steindachnerina aff elegans & & & 7.59 & 86.5 & & & 0.1 & & & 5.8 & 23 & & 43 & 4 & 7 & & 54 \\
\hline Anostomidae & & & & & & & & & & & & & & & & & \\
\hline Leporinus friderici & 1.8 & & 9.6 & & 72.8 & 14.4 & 1.2 & 0.2 & & & 4 & & 1 & 1 & 2 & & 4 \\
\hline Leporinus sp. & 5.9 & 0.3 & 40.9 & 0.9 & 29 & 2.1 & 0.7 & 20.1 & & & 15 & 1 & 1 & 1 & 19 & & 22 \\
\hline Leporinus sp. 3 & & & 94.1 & & & & & 5.9 & & & 1 & & & & & 1 & 1 \\
\hline Chilodontidae & & & & & & & & & & & & & & & & & \\
\hline Caenotropus labirinticus & 0.2 & & & 61.8 & & 24.7 & & & & 13.2 & 5 & & & & & 5 & 5 \\
\hline Lebiasinidae & & & & & & & & & & & & & & & & & \\
\hline $\begin{array}{l}\text { Pyrrhulina sp. } \\
\text { Strnonvoidae }\end{array}$ & 11.8 & 32.9 & 1.89 & 3.8 & & 43.9 & 0.4 & & & 5.3 & 42 & & 111 & & & & 111 \\
\hline Sternopygidae & & & & & & & & & & & & & & & & & \\
\hline Eigenmannia trilineata & 81.7 & 1.4 & 2.3 & 1.5 & 0.7 & 6.2 & & 0.1 & & 6.1 & 38 & & 58 & 14 & 24 & 5 & 101 \\
\hline Sternopygus macrurus & 23.6 & 0.1 & 5.23 & & 4.9 & 42.7 & & & & 23.4 & 6 & & 1 & & 1 & 6 & 8 \\
\hline Apteronotidae & & & & & & & & & & & & & & & & & \\
\hline Apteronotus albifrons & 77 & 3.1 & 3.8 & & & 15.3 & & & & 0.8 & 16 & & 2 & 10 & 6 & 2 & 20 \\
\hline Apteronotus sp. & 100 & & & & & & & & & & 2 & & & & & 2 & 2 \\
\hline Doradidae & & & & & & & & & & & & & & & & & \\
\hline Hassar orestis & 93.8 & & & 6.2 & & & & & & & 1 & & & & & 1 & 1 \\
\hline Hassar wilderi & 59.3 & 0.5 & & 39.6 & & & 0.4 & & & 0.2 & 2 & & & & & 2 & 2 \\
\hline
\end{tabular}


Table 1. (cont.)

\begin{tabular}{|c|c|c|c|c|c|c|c|c|c|c|c|c|c|c|c|c|c|}
\hline & & \multicolumn{9}{|c|}{ Types of food (\%) } & $\mathrm{N}$ & \multicolumn{4}{|c|}{ Abundance } & \multirow[b]{2}{*}{$\mathrm{E}$} & \multirow[b]{2}{*}{ Total } \\
\hline Families/species & $\mathrm{AI}$ & $\mathrm{TI}$ & $\mathrm{LF}$ & DT & $\mathrm{FS}$ & $\mathrm{AR}$ & $\mathrm{SC}$ & FA & $\mathrm{FH}$ & OT & & $\mathrm{A}$ & $\mathrm{B}$ & $\mathrm{C}$ & $\mathrm{D}$ & & \\
\hline \multicolumn{18}{|l|}{ Auchenipteridae } \\
\hline Tatia aulopygia & 9.3 & 90.7 & & & & & & & & & 1 & & & 1 & & & 1 \\
\hline \multicolumn{18}{|l|}{ Pimelodidae } \\
\hline Imparfinis sp. & 21.9 & 20.7 & 14.2 & & & 42.0 & & 0.3 & & 0.9 & 22 & & 1 & 20 & 12 & & 33 \\
\hline Phenacorhamdia sp. & 29.7 & 26.1 & 14.4 & 4.5 & & 25.2 & & & & & 21 & & & 14 & 13 & 1 & 28 \\
\hline Pimelodella cristata & 21.1 & 9.6 & 15.4 & 12.7 & 12.7 & 18.8 & 1.6 & & & 8.1 & 35 & & 12 & 13 & 30 & 2 & 57 \\
\hline Pimelodus blochii & 4.2 & 18.9 & 16.8 & & 25.8 & 8.1 & 4.5 & 4.8 & & 16.8 & 12 & & & & 6 & 17 & 23 \\
\hline Pimelodus maculatus & 47.9 & 1.9 & & & & 3.8 & & & 38.3 & 8.0 & 1 & & & & 1 & & 1 \\
\hline Surubim lima & & & & & & & & & 100.0 & & 1 & & & & 1 & & 1 \\
\hline Microglanis sp. & 14.3 & & & & & 85.7 & & & & & 6 & & & & & 9 & 9 \\
\hline \multicolumn{18}{|l|}{ Aspredinidae } \\
\hline Bunocephalus sp. & 10.0 & 56.3 & 7.9 & 0.5 & 3.3 & 21.2 & & & & 0.6 & 25 & & & & & 61 & 61 \\
\hline \multicolumn{18}{|l|}{ Cetopsidae } \\
\hline Pseudocetopsis plumbea & & 4.3 & & & & 95.7 & & & & & 3 & & & 3 & & & 3 \\
\hline \multicolumn{18}{|l|}{ Callichthyidae } \\
\hline Aspidoras sp. & 75.0 & 24.8 & & & & 0.1 & & & & 0.1 & 11 & 12 & & & 1 & & 13 \\
\hline \multicolumn{18}{|l|}{ Loricariidae } \\
\hline Hypoptopoma sp. & & & & 100.0 & & & & & & & 3 & & & & & 3 & 3 \\
\hline Hypostomus emarginatus & & & & 100.0 & & & & & & & 3 & & & & & 3 & 3 \\
\hline Hypostomus sp. 1 & & & & 97.5 & & & & 0.5 & & 2.0 & 33 & & 26 & 25 & 28 & 5 & 84 \\
\hline Hypostomus sp. 2 & & & & 100.0 & & & & & & & 6 & & 5 & 3 & & & 8 \\
\hline Hypostomus sp. 3 & & & & 100.0 & & & & & & & 17 & & 14 & 2 & 17 & & 33 \\
\hline Hypostomus sp. 4 & & & & 100.0 & & & & & & & 12 & & & & 17 & & 17 \\
\hline Loricaria sp. & 5.4 & & 7.7 & 24.9 & 50.2 & & & & & 11.8 & 35 & & 14 & 18 & 22 & 11 & 65 \\
\hline Parotocinclus britiskii & & & & 83.0 & & & & 2.0 & & 15.0 & 117 & & 269 & 58 & 18 & & 345 \\
\hline Pseudoloricaria sp. & 8.3 & 0.1 & 2.4 & 9.7 & & 1.3 & & 75.0 & & 3.1 & 47 & & 61 & 33 & 18 & 6 & 118 \\
\hline Spatuloricaria sp. & 36.7 & 0.9 & & 11.8 & 39.9 & 6.2 & & & & 4.4 & 12 & & 8 & 2 & 3 & 7 & 20 \\
\hline Sturisoma nigrirostrum & & & 0.5 & 90.0 & & & & & & 9.5 & 8 & & & 1 & & 7 & 8 \\
\hline Cochliodon sp. & & & & & & & & & & 100.0 & 2 & & & 2 & & & 2 \\
\hline Farlowella sp. & 1.0 & & 1.0 & 80.0 & & 1.0 & & 2.0 & & 15.0 & 20 & & 5 & 5 & 1 & 14 & 25 \\
\hline \multicolumn{18}{|l|}{ Rivulidae } \\
\hline Rivulus zygonectes & 6.1 & 51.9 & 4.8 & 1.3 & & 19.0 & 0.1 & 1.0 & & 15.7 & 141 & 350 & 2 & & 6 & 1 & 359 \\
\hline \multicolumn{18}{|l|}{ Cichlidae } \\
\hline Aequidens pallidus & 7.1 & 1.5 & 10.9 & 2.9 & 0.9 & 22.9 & 35.4 & & & 18.3 & 25 & 7 & 18 & 2 & 1 & 1 & 29 \\
\hline Crenicichla lugubris & 42.7 & 4.6 & 2.1 & 6.7 & & 3.7 & & 0.2 & & 40.0 & 26 & & 20 & 8 & 2 & 6 & 36 \\
\hline Geophagus surinamensis & 1.1 & & 21.1 & 10.6 & 3.4 & 38.1 & & & & 25.7 & 6 & & 1 & 4 & & 1 & 6 \\
\hline Retroculus lapidifer & 80.8 & & & 4.6 & 2.9 & & & & & 11.6 & 5 & & 2 & & & & 5 \\
\hline TOTAL & & & & & & & & & & & 1606 & & & & & & 3852 \\
\hline
\end{tabular}

fish fauna. On the other hand at Station B, where the native riparian vegetation has been totally removed, the importance of these food resources was the lowest among the five stations analyzed, again demonstrating the negative effect of deforestation. The most important species among the fruit and seed eaters at this station was Loricaria sp., which almost exclusively ingests seeds of the grass Brachiaria sp., an exotic species, used for pasture. These seeds fall into the water and accumulate on the bottom of the pools, where they are ingested by fish. Seed ingestion by Loricariidae is not common since these fish are usually algivores or detritivores (Lowe-McConnell, 1987). However, Goulding et al. (1988) attributed to a species of the genus Loricaria the use of aquatic insects in the diet. It is possible that this group is more generalist than thought thus far, using other types of food when they are available in larger amounts.

In the Córrego Fundo stream algae are of little importance as food. Pseudoloricaria sp. was the only species among the 20 most abundant ones that preferentially ingested algae.
Even though it was not numerous, it occurred at Stations B, $\mathrm{C}, \mathrm{D}$ and $\mathrm{E}$. Although generalist species have a better chance to become widely distributed (Lowe-McConnell, 1987), the fact that Pseudoloricaria sp. is the only algivore may be determinant for its wide distribution. Algae are rare in the Córrego Fundo stream but occur at all five stations, favoring Pseudoloricaria sp., which at low density obtains sufficient food from this resource.

Detritus is important for fish in the Córrego Fundo and is extensively used by South American fish (Petrere-Jr. 1978; Bowen, 1983; Lowe-McConnell, 1987). This resource represents an important food item (Fugi \& Hahn, 1991) due to the presence of large amounts of microorganisms associated (Keenleyside, 1979; Goulding, 1980). The large number of species that use detritus in the Córrego Fundo stream confirm that detritivory may be one of the most important forms of obtaining food by fish in tropical streams, as proposed by Lowe-McConnell (1987). Detritivores were absent only at station $\mathrm{A}$, a fact related to the high velocity. This intensive 
flows transport plant matter from the canopy forest to the lower region of the stream before its is transformed into detritus, preventing its use by fish at this site. In the lower portion several deposition pools retain detritus in the substrate, a fact that allows the occurrence of detritivores.

A greater proportion of detritivores was expected at Station E since, according to the River Continuum Concept (Vannote et al., 1980), a growing increase in detritus occurs in a water course from the source to the mouth. Although this guild gradually increases downstream, it is reduced at the mouth of the stream, where deforestation of the marginal soil prompt siltation, eliminating important microhabitats for detritus deposition, mainly the deeper pools. Among the most abundant detritivorous species are P. britskii, Hypostomus sp.1. Steindachnerina cf. elegans and Odontostilbe sp. The last one, although having no benthic adaptations like most detritivores, has been reported to adopt this same feeding strategy in other regions (Jacobo \& Veron, 1995). In addition, consumption of detritus by Odontostilbe sp. may be related to the type of feeding strategy, which allows the ingestion of detritus together with periphyton when the fish graze on it. In the pools where this species lives there are important deposits of sediments on the periphyton, which may be ingested involuntarily together with algae.

An important ecological characteristic of the neotropical fish fauna is the large proportion of piscivores (Santos et al., 1984; Mérona, 1986/87; Lowe-McConnell, 1987; Braga, 1990) commonly present in sympatry or even in syntopy (Nico \& Taphorn, 1988; Winemiller, 1989). Although the use of fish as food provides high quality nutrients, this feeding strategy requires complex adaptations that will lead the predator to overcome the defenses of the prey (Keenleyside, 1979; Sazima \& Machado, 1990; Wootton, 1990; Winemiller, 1991, 1992). Piscivores are rare in the Córrego Fundo stream and mainly occur during the rainy season when they migrate to this stream.

Carnivores are mainly represented by terrestrial insect eaters. The abundance of this fish group is related to the easy capture of insects, which are defenseless when they fall in the water (Mason \& MacDonald, 1982). Furthermore, the preferred prey is that for which the cost/benefit ratio between ingestion and energy for capture is minimized (Pianka, 1978; Wootton, 1990). Since insects are rich in nutrients, especially proteins (Nico \& Morales, 1994), their ingestion is an advantage for fish with this habit at sites where riparian vegetation is abundant, as Rivulus zigonectes at Station A. At Station B, species that most often used this resource was Bryconops giacopinii which is rare in this site. The low occurrence of fish using this item coincides with the absence of forest canopy in this area, since this guild are well represented by $B$. giacopinii and Bunocephalus sp. at Stations $\mathrm{C}$ and E, respectively. The absence of this group at Station D was due to the high speed of the water, which prevents the collection of items falling on the surface due to the turbulence of the current.

Although aquatic insects may represent an abundant food source for fish, they are mainly ingested by predators with special adaptations, since in this case, prey may have antipredator defenses (Keenleyside, 1979). In the Córrego Fundo stream this item was mainly ingested by Aspidoras sp. (Station A), Eigenmannia trilineata (Station B), and Pimelodella cristata (Station C and D). These species have, in addition to a visual system, other senses that permit them to locate their prey (Tejerina-Garro et al., 1998).

Generalization of feeding habit is frequently attributed to stream fish (Lowe-McConnell, 1987). Cluster analysis demonstrates that the trophic groups are well defined and even though generalist groups do occur, in most cases there are predominant food items in the diet of fish. This demonstrates that the fish community in these environments may be much more specialized in terms of feeding than currently assumed.

Thus, among the fish of the streams in this region, feeding is closely related to canopy forest and to geomorphological characteristics of the stream, as depth, width, steepness of slope and substrate type, with well-defined and distinct trophic groups for different environments.

Man-made environmental changes can significantly affect the structure of some fish populations in these systems: directly, by removal of the forest canopy that provides allochthonous food, and indirectly by siltation that causes destruction of microhabitats that act as food deposits and shelters.

In this case, the rapid deforestation of the savannas of Central Brazil for the introduction of agriculture and pastures may place at risk many fish species that have not even been described scientifically.

\section{Acknowledgements}

We thank Jesus F. Melo for providing vehicles, the biologists MSc. Alexandre Milaré Batistella and Maria das Dores Santos for help in the field and laboratory, Valdemar Marcolan, Dr. Paulo Cesar Venere and Braulina da Silva Morbeck from ICLMA/UFMT, for facilities with laboratories and equipments, and MSc. Jane Dilvana Lima for reading and correcting this manuscript.

\section{Literature Cited}

Allan, J. D. 1995. Stream Ecology: structure and function of running waters. Chapman \& Hall, London, 388p.

Bowen, S. H. 1983. Detritivory in neotropical fish communities. Environmental Biology of Fishes, 9 (2): 137-144.

Braga, F. M. S. 1990. Aspectos da reprodução e alimentação de peixes comuns em um trecho do rio Tocantins entre Imperatriz e Estreito, estados do Maranhão e Tocantins, Brasil. Revista Brasileira de Biologia, 50 (3): 547-558.

Britski, H. A, K. Z. S. Silimon \& B. S. Lopes. 1999. Peixes do Pantanal: manual de identificação. Embrapa, Brasília, 184p.

Esteves, K. E. \& J. Lobón-Cerviá. 2001. Composition and trophic structure of a fish community of a clear water Atlantic rainforest stream in southeastern Brazil. Environmental Biology of Fishes, 62: 429-440. 
Fittkau, E. J. 1967. On the ecology of Amazonian rain-forest streams. Atas Simpósio Biota Amazônica, 3 (limnologia): 97-108.

Fugi, R. \& N. S. Hahn. 1991. Espectro alimentar e relações morfológicas com o aparelho digestivo de três espécies de peixes comedores de fundo do Rio Paraná, Brasil. Revista Brasileira de Biologia, 51 (4): 873-879.

Gottsberger, G. 1978. Seed dispersal by fish in the inundated Regions of Humaitá, Amazonia. Biotropica, 10 (3): 170183.

Goulding, M. 1980. The fishes and the forest: explorations in Amazonian natural history. University of California Press, Berkeley, 280p.

Goulding, M., M. L. Carvalho \& E. G. Ferreira. 1988. Rio Negro: rich life in poor water. SPB Academic Publishing, Netherlands, 200p.

Henry, R., V. S. Uieda, A. A. O. Afonso \& R. M. Kikuchi. 1994. Input of allochthonous matter and structure of fauna in a Brazilian headstream. Verhandlungen der Internationale Vereinigung fur Theoretishe und Angewandte Limnologie, 25: $1867-1869$.

Jacobo, M. A. C. \& M. B. C. Veron. 1995. Relaciones troficas de la ictiofauna de cuencas autoctonas del chaco oriental. Argentina. Revista Brasileira de Biologia, 55(3): 419-437.

Keenleyside, M. H. A. 1979. Diversity and adaptation in fish behaviour. Springer Verlag, Berlim, 208p.

Krebs, C. J. 1989. Ecological methodology. Harper \& Row, New York, 654p.

Lowe-McConnel, R. H. 1987. Ecological studies in tropical fish communities. Cambridge University Press, Cambridge, 382p.

Mason, C. F. \& S. M. MacDonald. 1982. The input of terrestrial invertebrates from tree canopies to a stream. Freshwater Biology, 12: 305-311.

Mérona, B. 1986/87. Aspectos ecológicos da ictiofauna no baixo Tocantins. Acta Amazonica 16/17: 109-124.

Nico, L. G. \& M. Morales. 1994. Nutrient content of piranha (Characidae, Serrasalminae) prey items. Copeia 2: 524-528.

Nico, L. G. \& D. C. Taphorn. 1988. Food habits of piranhas in the low llanos of Venezuela. Biotropica, 20: 311-321.

Novaes-Pinto, M. 1993. Caracterização do Distrito Federal. Pp. 285-320. In: Novaes-Pinto, M. (Ed.). Cerrado: caracterização, ocupação e perspectivas. UnB, Brasília, 681p.

Oyakawa, O. T. \& K. E. Esteves. 2004. Métodos de amostragem de peixes de água doce. Pp. 231-243. In: Bicudo, C. E. M. \& D. C. Bicudo (Eds.). Amostragem em Limnologia. Rima,
São Carlos, 2004. 371p.

Petrere-Jr, M. 1978. Pesca e esforço de pesca no Estado do Amazonas II - Locais, aparelhos de captura e estatística de desembarque. Acta Amazônica, 8 (3): 1-54.

Pianka, E. R. 1978. Evolutionary Ecology. 2a ed. Harper \& Row, New York, 395p.

Prejs, A. \& K. Prejs. 1987. Feeding of tropical freshwater fishes: seasonality and resource use. Oecologia, 71: 397-404.

Santos, G. M., M. Jegu \& B. Mérona. 1984. Catálogo de peixes Comerciais do Baixo rio Tocantins; Projeto Tucuruí. Eletronorte/Cnpq/Inpa, Manaus, 83p.

Sazima, I. \& F. A. Machado. 1990. Underwater observations of piranhas in western Brazil. Environmental Biology of Fishes, 28:17-31.

Tejerina-Garro, F. L., L. Fortin \& M. A. Rodríguez. 1998. Fish community structure in relation to environmental variation in floodplain lakes of the Araguaia River, Amazon Basin. Environmental Biology of Fishes. 51: 399-410.

Vannote, R. L., G. W. Minshall, K. W. Cummins, J. R. Sedell \& C. E. Cushing. 1980. The river continuum concept. Canadian Journal of Fisheries and Aquatic Sciences, 37: 130-137.

Vari, R. P. \& L. R. Malabarba. 1998. Neotropical Ichthyology: An overview. Pp. 1-11. In: Malabarba, L. R., R. E. Reis, R. P. Vari, Z. M. S. Lucena (Eds). Phylogeny and Classification of Neotropical Fishes. Edipucrs, Porto Alegre, 603p.

Winemiller, K. O. 1989. Ontogenetic diet shifts and resource partitioning among piscivorous fishes in the Venezuelan llanos. Environmental Biology of Fishes, 26: 177-199.

Winemiller, K. O. 1991. Ecomorphological diversification in lowland freshwater fish assemblages from five biotic regions. Ecological Monographs, 61: 343-363.

Winemiller, K. O. 1992. Ecomorphology of freshwater fishes. Research \& Exploration 8: 308-327.

Wootton, R. J. 1990. Ecology of Teleost Fishes. Chapman and Hall, New York, 404p.
Received April, 2004

Accepted April, 2004 